\title{
The German Model and Dual System: A Skills Initiative for the US?
}

\author{
Billie Jo Hernandez, PhD \\ Adjunct Assistant Professor, Department of Political Science, John Jay College of Criminal Justice \\ City University of New York, United States
}

\begin{abstract}
This paper compares capitalism in Germany and the United States. It specifically looks at the Dual System of Vocational Training and Education in the German Model of capitalism. This paper argues that there are features of the Dual System that can be applied to the US economy that can reduce unemployment, create jobs, build a highly skilled workforce from unused potential, and provide opportunity for the successful resurgence of the American manufacturing sector. Doing so, the US can reassert its hegemony among global economic powers and promote individual development and achievement of American youth.
\end{abstract}

Keywords: The German Model, dual system, vocational training, varieties of capitalism, workforce development, political economy, education

\section{Introduction}

Germany is the largest economy in the European Union and is a major trade partner with the United States. Over 3,400 German companies have investment in the US. The size of these companies range from small and medium-sized firms to large multi-national corporations. At the end of 2014, German business investment in the US totaled \$244 million, amounting to 7.7 percent of the total \$2.9 trillion dollars of investment in the United States by foreign companies. Overall, German companies have created 620,000 jobs in the US. [1]

This paper contributes to the discussion on capitalism in two ways: First, it adopts the Varieties of Capitalism approach in political economy to explain some key differences in German and American capitalism. This allows the reader to understand that capitalism does not look the same, or function in the same way across developed countries, or even across advanced Western democracies. In particular, the role of the firm with regard to and training and education is very different in the US than in Germany.

Second, this paper explores the dual system. The dual system is a feature of German capitalism that is responsible for more than half of high school graduates in Germany. In this system, firms provide practical training while vocational schools provide theoretical instruction. The dual system, as a model for youth education and training has been adopted in Austria, Switzerland and France. Recently, vocational training projects based on the German Model are in practice in China, Italy, Spain, India, Thailand, Brazil, Greece, Portugal, and Russia. [2] Is there a future for the dual system in the United States? This paper examines the efforts made by German firms and other actors in the US to implement a dual training system and the response by US government to those efforts.

\section{Varieties of Capitalism: What is the German Model?}

The term German Model is short for "The German Model of capitalism." The German Model is used to describe how the German economy is set up and how it works- its structures, industrial practices, the behavior of economic actors, and the role of the State. Sometimes referred to as "Rhine Capitalism", Germany's brand of capitalism has been considered a model to emulate, based on West German economic success after the Second World War.

The "Varieties of Capitalism" (VOC) [3] approach is a theoretical framework in comparative political economy. Pioneered by Hall and Soskice in 2001, the VOC approach centers around the firm. It attempts to classify and understand the differences in economic and political institutions across developed economies. According to Hall and Soskice, there are two varieties of capitalism in advanced industrial democracies: a 
coordinated market economy and a liberal market economy. Germany is a coordinated market economy. The United States is a liberal market economy.

\section{Key Differences between the German Model and American Capitalism}

There are several key differences between the German variety of capitalism and the American variety of capitalism according to the VOC approach. For example, we can observe that firms behave very differently in each economy with regard to education and training systems. Studying these differences also sheds light on differences in political culture and operational norms of firms.

\subsection{Education and Training System in Germany}

Germany, as a coordinated market economy, equips their labor with industry specific and firm specific skills. Firms depend on education and training systems that provide workers with such skills. These workers start out as apprentices or trainees. Moreover, firms are expected to take on apprenticeships. Germany has industry wide employer associations and trade unions that supervise the training system. They also negotiate the wages of trainees for each industry. The training systems are publically subsidized by the government. Because industry associations monitor the training, free-riding on the training of others is virtually eliminated. The result of such a system is that industry wide skills and firm specific skills practically guarantee a young apprentice employment at the firm at which they are training or another firm within the same industry. At the same time, skilled workers boost a firm's competitiveness.

\subsection{Education and Training in the United States}

The education and training systems of liberal market economies look very different than that of coordinated market economies. In the US, training is typically offered by schools that provide general skills training. American firms are hesitant and resistant to invest in apprenticeship programs that teach industry specific skills, in part because of the fact that other firms can easily poach their apprentices. The poacher will not invest in training. Instead it will free-ride on the investment of another firm. This is pre-empted in a coordinated market economy. Nevertheless, the education system in the United States is highly respected and emulated, especially at university level. But in a highly fluid labor market such as the US, specific training takes the form of in-house training after a worker is hired, not union-employer association and firm negotiated apprenticeship programs as in Germany.

\section{What is the Dual Training System in the German Model of Capitalism?}

The German dual system is one of several paths that a student can take after completing high school. The dual apprenticeship system is also called the dual system of vocational training, dual being the key word here. In this case, dual refers to two venues of education, combined into one system. A student receives on the job training in addition to further in-classroom instruction. While a typical vocational training may be in the crafts or agriculture field, a civil or public servant studying diplomacy may also participate in the dual system after High School.

The vocational training system in Germany is a collaboration between the public and private sectors which serve to directly or indirectly provide occupational qualifications. [4] It is legally regulated by the Vocational Training Act. Unlike internships in the US in which youth earn little or no pay and rarely receive formal training, apprenticeships in German vocational training follow an "earn while you learn" model. They are employed in actual jobs and classroom training. Furthermore, dual system participants practically have a guarantee of a job after that student has earned his state recognized credentials.

Vocational training is based on institutional procedures and tripartite negotiations that involve three major actors: public authorities, employers' organizations and trade unions. School based training is paid for by the state and practical training costs are paid for by the firms in which the trainee is placed for their apprenticeship. The Federal Employment Agency pays for 15\% while the German federal states pay about 10\%. Firms contribute the most to the cost of training, or about $75 \%$. This is not a standard practice of firms in the US.

Typically, a student in the dual system with learn in the company 3-4 days per week under the framework of a training contract which includes state recognition of the occupation, overall training plan and examination 
requirements. The rest of the week, between 1-2 days, a trainee will go to school. While students do have the option to attend full time vocational schools this is not the path of the dual training system. The dual trainee will attend school and train at the same time. In a vocational school the vocational subject comprises two- thirds of the curriculum while general subjects are one-third. Final qualification is state recognized and upon completion a student will receive a chamber certificate. Altogether, the duration of a dual training track takes around three or three and a half years.

Training occupations are found in almost every sector of the German economy and date back to the Middle Ages: industry, commerce skilled trades, office administration, banking, health and agriculture. In total there are 348 training occupations. Examples, of occupations including machine and plant operator, micro-technologist and recycling and waste management technician, custom tailor, biology laboratory technician and mechatronics technician. Some occupations are highly specialized whereas some cut across different branches such as office clerk.

At the end of his or her training, a German vocational student is entitled to practice an occupation as a qualified skill worker. In 2015, there were approximately 1.5 million young people in dual vocational education and training. All students receive apprenticeship pay during their time in the program. The pay is regulated by collective bargaining agreements. For example, a mechatronics engineering trainee earns 950 Euros per month, gross. The pay increases with each year of training completed. [5]

In Germany today, about 90 percent of all large-scale enterprises with 500 or more employees and 70 percent of all medium sized businesses offer vocational training positions. Nearly every second firm with between 10-49 employees is a company with trainees. Small sized businesses with up to 10 people employed also offer apprenticeships at around 14 percent. In total, over 500,000 German firms offered apprenticeship positions. [6] Simply put, the dual system is a way of life in Germany's labor supply and overall organization of the economy. It is a major distinguishing factor between Germany's coordinated market economy and the US liberal market economy.

\section{What are the Benefits of the German Vocational Education System for the US?}

The following benefits of the German dual system can be simultaneously seen as potential benefits for the American economy. First, young people can receive a recognized certificate that shows that they have high technical skills in a particular trade or craft. They also receive practical orientation and relatively high apprenticeship pay. Second, in terms of industry, there are industry-wide benefits from securing skilled labor, reducing costs of settling in of new workers, and job specific qualifications for new workers. Finally, at state and society level, the benefits are relatively low rate of youth unemployment, the possibility to offer school graduates vocational training and private sector contribution to ease the burden on public budgets.

Germany has one of the world's lowest youth unemployment rates at $7.7 \%$ in 2015 . Youth is defines as a worker aged 16-24. The United States has an overall youth unemployment rate of $10.8 \%$ in April 2016. [7]Taking a look at state levels, there are some states that have much higher youth unemployment rates than others. For example, South Carolina has youth unemployment rate of $16.2 \%$, versus Texas at $9.3 \%$, Georgia at $14.6 \%$, West Virginia at $17.4 \%$ and New York at $14.2 \%$. [8] These numbers vary even more when considering regions within states. In south Texas for example, the youth unemployment rate stands significantly above the rate in northern Texas. This is untapped potential of American labor and youth.

Expanding the apprenticeship program to the United States would help strengthen the US economy. There are not enough skilled workers to meet future economic needs. [9] By 2020, the US is projected to experience a shortage of 3 million workers with associate's degrees or higher and 5 million workers with technical certificated and credentials. Industry leaders have argued that a lack of qualified workers is a top concern for many employers. [10]

Yet, most American firms are not willing to go beyond a few weeks of learning on the job and the US corporate sector does not see technical and vocational training as one of its key responsibilities. [11] The average age of a high-skill manufacturing worker in the US is 56 years old, and even today the US faces a shortage of workers. In 2012, Deloitte found that there were 600,000 unfilled manufacturing jobs in the US. 
Can the dual training system be applied to the US economy to boost youth employment in manufacturing? A main question that comes to mind from an employer perspective is: Who is going to pay for the training? [12] Still, the German Model of dual training is a viable model and should be tailored to fit the needs of individual countries if used outside of Germany. Whether or not it will be used in the US is no longer the question- the question is to what extent?

\section{The German Dual System already in the US?}

In 2013, 200 companies in the US (or half of the firms surveyed) expressed a concern about finding skilled workers to fill jobs, many of them well paid. [13] Furthermore, German companies have identified the problem of finding skilled labor as a major challenge to their success in the US. The dual system is not only a reason for Germany's economic success, but is a viable alternative to employment versus a traditional university education. The dual system is not a vocational school such as ITT Technical School or Apex Technical School in the US. It is a program in which companies are directly invested in the students' success and have partnered with schools to train workers for future hire. Sound qualifications and recognized skills gained after high school combine theory and practice. The dual system shows that technical trades and crafts can in fact be highly valued and immediately applicable in the job market.

Volkswagen (VW) in Tennessee is the first German company to establish an apprenticeship company in the United States. In August 2013, twelve students earned their Automation Mechatronics certificates by the Association of German Chambers of Commerce and Industry and the German American Chambers of Commerce. [14] These students are the first to graduate in a program modeled after the dual training system. VW invested $\$ 40$ million in the new training academy and the students are trained by VW experts and a German apprenticeship trainer. The final result is a Volkswagen specific trained graduate who is then hired by the Tennessee plant, filling a gap in skilled labor that VW needed. In addition, the state of Tennessee will provide a $\$ 12$ million grant for training new employees.

While the model is not exported as an exact copy, many community colleges and American companies are establishing training programs that pick the best elements from the model and apply them to co-create a US traineeship. Another example of a dual training inspired program at work in the US is the Michigan Advanced Technician Training (MAT2). Michigan is known for its automobile production. The MAT2 is based on coupling apprenticeship with employer commitment. The idea for the program came from the Michigan governor who visited Germany. Seven German firms, three US firms and one French firm are taking part in MAT2. [15]

Festo Didactic AG a German company based in New Jersey (NJ) that acquired US-Canadian Lab-Volt also has a training program in place. Festo is known for establishing labs and high-tech facilities to train workers. They have partnered with community colleges in NJ as well as North Carolina where the company will open a training facility directly on the college campus. [16] All firms promote a career in manufacturing.

\subsection{Joint Declaration by US and Germany Regarding Skills Training}

On June 5, 2015, government officials from both the US and Germany signed the Joint Declaration in Washington DC. Together with the German Federal Ministries of Education and Research, Economic Affairs and Energy and Labor and Social Affairs, the US Department of Commerce, US Department of Labor and US Department of Education crafted the Joint Declaration of Intent with the eventual goal of recognizing certificates, exchange of best practices and cooperation between companies on skills training. [17]

Both US and German companies will benefit from the Joint Declaration to fill the skills gap. Finding skilled labor to maintain these positions is critical. By training workers and guaranteeing young people a job right after training is complete, youth unemployment decreases and companies find the labor they are looking for. German Chancellor Angela Merkel stated the Germany's apprenticeship programs are the reason for the low youth unemployment rate. Germany has the lowest youth unemployment rate in the European Union at $7.7 \%$, compared to the EU average of 22.2\%. [18]

Expanding apprenticeships in the US will require overcoming many hurdles and potentially creating new government institutions. It will also require a shift in corporate culture and an increased awareness of the range of possible vocations that are beyond the traditional trades such as construction or plumbing. Placing highly 
skilled workers in jobs and maintaining a low unemployment rate is an economic priority of any advanced industrial democracy. Applying some elements of the German model that are do-able for American companies and government would yield tremendous benefits to the US economy, increase youth employment and confidence as well as help reassert American hegemony among global economic powers.

\section{Conclusion}

This paper has demonstrated that the German Model of capitalism, as a coordinated market economy is distinct from capitalism in the US, or liberal market economy regarding education and training. Furthermore, we have seen that the German dual system of training has the possibility of unlocking potential for the American economy, specifically for youth employment enabling businesses to boost their productivity. Finally, it is confirmed that federal level political institutions in the US have signed a joint declaration with German government to recognize the importance of supporting education and training programs that are built in partnership and cooperation with employers.

\section{References}

[1] Embassy of the Federal Republic of Germany. Washington DC. Available: www.Germany.info/skillsinitiative

[2] German-Thai Chamber of Commerce Available: http://thailand.ahk.de/en/vocational-education/about-the-gtdeeprogramme/

[3] P. Hall and D. Soskice, Varieties of Capitalism. The Institutional Foundations of Comparative Advantage. Oxford University Press, UK. 2001, Ch. 1.

http://dx.doi.org/10.1093/0199247757.001.0001

[4] D. Tremblay and I. Le Bot, The German Dual Apprenticeship system. Analysis of its evolution and its present challenges. February 2003,pg. 12. Available: https://www.teluq.uquebec.ca/chaireecosavoir/pdf/NRC03-04A.pdf

[5] Vocational Training and Pay. Available: http://www.make-it-in-germany.com/en/for-qualified-professionals/traininglearning/training/vocational-training-in-germany-how-does-it-work

[6] German companies want to hire Europe's young unemployed. Deutsche Welle, July 22, 2015. Available: http://www.dw.com/en/german-companies-want-to-hire-europes-young-unemployed/a-18598791

[7] Statista. Available: http://www.statista.com/statistics/217448/seasonally-adjusted-monthly-youth-unemployment-ratein-the-us/

[8] Where youth unemployment is highest and lowest. March 7, 2016.Available: http://www.governing.com/topics/mgmt/gov-youth-unemployment-states.html

[9] [9] S. Steigleder and L. Soares, L. Let's Get Serious About Our Nations Human Capital.Washington: Center for American Progress, 2012.

[10]B. Olinsky and S. Ayers, Training for Success. Center for American Progress, December 2013.

[11] Would German Style Apprenticeships Work in The US? Bloomberg Business Jan 20, 2014.

[12] G. Sherer, L'Oreal USA Headquarters, New York, USA. 2014

[13] US President, State of the Union Address 2014.

[14] Volkswagen Trainees First in the US Receive German Apprenticeship Certificate. August, 2013. Available: http://busride.com/2013/08/volkswagen-trainees-first-in-u-s-to-receive-german-apprenticeship-certificate/

[15] Governor Rick Snyder of Michigan. Available: http://www.michigan.gov/snyder/0,4668,7-277--319770--,00.html

[16] German-Style Training for American Factory Workers Wall Street Journal, September 9, 2014. Available: http://www.wsj.com/articles/german-style-training-for-american-factory-workers-1410296094

[17]Joint Declaration of Intent on Vocational Training, June 5, 2015. Available: http://www.rgit-usa.com/newsmodul/news-single/artikel/joint-declaration-of-intent-on-vocationaltraining/?cHash=47c8ffc611d4df10fab1d9fe8d85fbbf

[18] Germany has lowest youth unemployment in EU. August 11, 2015. Available: http://www.dw.com/en/germany-haslowest-youth-unemployment-in-eu/a-18640125 